\title{
TITLE: TAXATION OF THE DIGITAL ECONOMY IN NIGERIA: THE POST-COVID
}

WORLD

\section{AUTHOR: YAHAYA MARIAM OLUWAPELUMI}

\subsection{INTRODUCTION}

The world economy has undergone drastic changes majorly due to the rapid growth of digitalization and the covid-19 pandemic leading to an increased demand for online services . 1

The global market is currently experiencing a paradigm shift from the traditional economy model

to a digital economy model, ${ }^{2}$ with investors capitalizing on this movement by investing heavily on digital services such as cryptocurrency, social media platforms, online shopping, online gaming etc.

Nigeria is no stranger to the movement with the National Bureau of Statistics reporting that the ICT sector contributed 17.83 per cent to Nigeria's GDP in the second quarter of $2020 .^{3}$

Moreover, due to fluctuating oil prices and the covid-19 pandemic which has increased the dependency on digital services, given that physical transactions has become limited due to the need to social distance. ${ }^{4}$ Therefore, a need arises to make stringent polices to better tax the digital economy.

\footnotetext{
1 'VAT Challenges for the Digital Economy' (KPMG) https://home.kpmg/xx/en/home/insights/2019/01/vatchallenges-for-the-digital-economy.html accessed $26^{\text {th }}$ August 2020.

${ }^{2}$ Fatai Folarin, Seye Arowolo and Yomi Olugbenro, 'why should tax be on digital flight from Nigeria?' (Deloitte) https://www2.deloitte.com/ng/en/pages/tax/articles/inside-tax-articles/why-should-tax-be-on-digital-flight-fromnigeria.html accessed 26th August 2020.

${ }^{3}$ Oge Udegbunam, 'ICT's Contribution to Nigeria's GDP increases in spite of economic slowdown' Premiumtimesng (Abuja, 25 August 2020) https://www.premiumtimesng.com/business/410695-icts-contribution-to-nigerias-gdpincreases-in-spite-of-economic-slowdown.html accessed 26th August 2020.

${ }^{4}$ AGO Group, 'Coronavirus-Africa: Taxing the digital economy- COVID-19 heightens need to expand resource mobilization base' The Guardian (26 August 2020) https://guardian.ng/apo-press-releases/coronavirus-africataxing-the-digital-economy-covid-19-heightens-need-to-expand-resource-mobolization-base/ accessed $26^{\text {th }}$ August 2020.
} 


\subsection{EVALUATION OF THE NIGERIAN APPROACH IN TAXING DIGITAL}

\section{ACTIVITIES}

Taxing the digital economy prior to 2020 posed a difficult challenge, due to requirement to prove 'permanent establishment' in Nigeria for non- resident companies (NRC) $)^{5}$ and also there exist no global agreement on how to tax the digital economy. ${ }^{6}$ Despite the lack of international consensus on taxation of the digital economy, The Nigerian government in recognition of the importance of the digital economy signed into law the Finance Bill (now Act). The Act introduced multiple changes to various tax legislations in Nigeria including the Company Income Tax Act (CITA) and the Value Added Tax Act (VATA). ${ }^{7}$ The importance and challenges posed to the digital economy by the changes to the aforementioned legislation will be discussed below:

\subsection{COMPANY INCOME TAX}

Prior to the enactment of the Finance Act, Section 13(2) of the CITA which provides the basis assessing CIT liability on the profit of an NRC in Nigeria did not contemplate the taxation of income derived from digital activities, due to its limited scope and its emphasis on having a permanent establishment in Nigeria. ${ }^{8}$ But the newly enacted Finance Act lays emphasis on having a "significant economic presence"(SEP) and what constitute SEP has been spelt out by the minister of finance in the Companies Income Tax (Significant Economic Presence) Order

\footnotetext{
${ }^{5}$ Companies Income Tax Act 2007, s 13

${ }^{6}$ Abubakar Idris, 'Inside the Finance Bill: Nigeria is Planning to Introduce Digital Taxes' (Techcabal, 15 January 2020) https://techbal.com/2020/01/15/inside-the-finanace-bill-nigeria-is-planning-to-introduce-digital-taxes accessed $26^{\text {th }}$ August 2020.

${ }^{7}$ Dipo Komolafe and Okabonye Chukwani, 'The Impact of the Finance Act on Digital Taxation in Nigeria'(Mondaq 21 May 2020) < https://www.mondaq.com/nigria/tax-authorities/903148/the-impact-ofthe-finance-act-on-digitaltaxation-in-nigeria $>$ accessed $26^{\text {th }}$ August 2020.

8 Ibid.
} 
2020. ${ }^{9}$ The order is wide-spread and succeeded in capturing digital activities into the tax net. Nevertheless, this innovation has some challenges.

\subsubsection{CHALLENGES}

A major challenge is the uncertainty of how the FIRS will enforce the order and also how to determine the amount of profit that is taxable,${ }^{10}$ The Organisation for Economic Cooperation and Development (OCED) consultation document on tax challenges of the digitalisation of the economy suggests that only portion of the profit should be taxed in the jurisdiction where the NRC has significant economic presence, but it is difficult to say if it will apply in Nigeria due to the principle of profit attribution stipulated in the Income Tax(Transfer Pricing) Regulation $2018^{11}$ and the recent decision of the Tax Appeal Tribunal in Prime Plastichem Nigeria Limited V FIRS. ${ }^{12}$

There are also growing concerns in regards to the interplay between the Nigerian double taxation treaties (DTT) and the Order by the Minister of Finance because based on international practices the DTT supersede the Order and should not apply to countries that has DTT with Nigeria. ${ }^{13}$

\subsection{VALUE ADDED TAX}

The Finance Act is majorly known for increasing the rate of VAT to $7.5 \%$ in Nigeria but it also increased the scope of vatable goods to include intangible goods which encapsulates digital

\footnotetext{
${ }^{9}$ Ugochukwu Eze and Ifeatu Medidem, 'Taxation of Non-Resident Companies with Significant Economic Presence in Nigeria'(Proshare, 4 August 2020) http://www.proshareng.com/news/Taxes\%20\&\%20Tarrifs/Taxation-of-NonResident-Companies-with-Significant-Econonic-Presence-in Nigeria/52579 accessed $26^{\text {th }}$ August 2020.

10 Ibid.

11 ibid

${ }^{12} \mathrm{TAT} / \mathrm{LZ} / \mathrm{ClT} / 015 / 2017$

${ }^{13}$ Victor Adegite and Wole Obayemi, 'Taxation of Digital Economy in Nigeria-Significant Economic Presence' (Bloomberg Tax, 31 December 2019) https://newa.bloombergtax,com/digital-tax-report-international/insighttaxtion-of-digital-economy-in-nigeria-significant-economic-presence accessed $26^{\text {th }}$ August 2020.
} 
activities. ${ }^{14}$ Prior to the enactment of the Finance Act, Nigeria government was faced with the challenge of whether the government could tax cross-border supplies that are delivered by a supplier who has no physical presence in Nigeria to a customer within Nigeria, ${ }^{15}$ this is particularly due to the clash in provisions of the VATA which did not provide for taxing of cross border supplies by a supplier who has no physical presence and the court which have held this goods and services to be taxable by applying the 'destination principle'. ${ }^{16}$ The Finance Act solved this challenge by amending the VATA to reflect the destination principle. Consequently, if an NRC supplies digital goods to persons in Nigeria such goods are now subject to VAT. ${ }^{17}$

\subsubsection{CHALLENGES}

The significant improvement made to the VATA does not come without challenges. A major challenge is the threat of double taxation and the requirement that all NRC carrying out business

in Nigeria must be registered for VAT which is impracticable and an unnecessary administrative burden. $^{18}$

\subsection{EVALUATION OF THE INTERNATIONAL APPROACH IN TAXING DIGITAL ACTIVITIES}

\footnotetext{
${ }^{14}$ Dipo Komolafe and Okabonye Chukwani, 'The Impact of the Finance Act on Digital Taxation in Nigeria'(Mondaq 21 May 2020) <https://www.mondaq.com/nigria/tax-authorities/903148/the-impact-ofthe-finance-act-on-digitaltaxation-in-nigeria> accessed $26^{\text {th }}$ August 2020.

15 'VAT Challenges for the Digital Economy' (KPMG) https://home.kpmg/xx/en/home/insights/2019/01/vatchallenges-for-the-digital-economy.html accessed 26 th August 2020.

${ }^{16}$ Vodacom Business Nigeria Limited v FIRS (2019) LPELR-47865(CA)

${ }^{17}$ Dipo Komolafe and Okabonye Chukwani, 'The Impact of the Finance Act on Digital Taxation in Nigeria'(Mondaq 21 May 2020) < https://www.mondaq.com/nigria/tax-authorities/903148/the-impact-ofthe-finance-act-on-digitaltaxation-in-nigeria) accessed $26^{\text {th }}$ August 2020.

18 'FIRS Issues Information Circular on the Implementation of VAT Changes in the Finance Act' (Proshare, 5 May 2020) https:///www.proshareng.com/news/Taxes\%20\&\%20Tariffs/FIRS-Issues-Information-Circular-on-theImplementation-of-VAT-Changes-in-the-Finance-Act/50857 accessed $1^{\text {st }}$ September 2020.
} 
There exists no global agreement on the taxation of the digital economy, the Organisation for Economic Cooperation and Development which Nigeria is a member have yet to come up with a proposal that can be agreed on by all its members. ${ }^{19}$ Thus, due to the lack of an international agreement countries are now at odds with each other on how to tax revenue generated by digital companies. ${ }^{20}$ An example is the dispute that occurred between the United States(US) and the European Union(EU) with the United States asserting that digital taxes unfairly discriminate US businesses and threatened to retaliate through tariffs. ${ }^{21}$ Thus, due to the sensitive nature of the digital economy which does not respect jurisdictional boundaries, the importance of an international consensus on its taxation is vital for an effective taxation system.

Notwithstanding, the lack of an international agreement several countries have adopted similar unilateral measures in a bid to remedy the tax challenges of the digital economy. ${ }^{22}$

\subsection{KENYA}

Nigeria's current position on digital tax is similar to that of Kenya, ${ }^{23}$ but a significant difference between the two is that Nigeria's Finance Act seems not to elaborate on its enforcement plan while Kenya is taking appropriate steps on the enforcement of this taxes, this is seen in the newly

\footnotetext{
${ }^{19}$ Frank Eleanya,'Nigeria's Digital Tax Plan Could Unlock New Revenue, but hurdles lie ahead'(Business Day, 30 June 2020) https://businessday.ng/technology/article/nigerias-digital-tax-plan-could-unlock-new-revenuse-buthurdles-lie-ahead accessed $26^{\text {th }}$ August 2020.

20 ibid

21 ibid

${ }^{22}$ Ademola Idowu, Victor Adegite and Wole Obayemi, 'Taxation of Digital Economy in Nigeria's Finance Bill' (Enugumetro 31 May 2020) https://enugumetro.com/taxation-of-digital-economy-in-nigerias-finance-bill-2019 accessed $26^{\text {th }}$ August 2020.

${ }^{23}$ Frank Eleanya, 'Nigeria's Digital Tax Plan Could Unlock New Revenue, but hurdles lie ahead' (Business Day, 30 June 2020) https://businessday.ng/technology/article/nigerias-digital-tax-plan-could-unlock-new-revenuse-buthurdles-lie-ahead accessed $26^{\text {th }}$ August 2020.
} 
released Value Added Tax(Digital Marketplace Supply) Regulation 2020 draft as a proposed guideline for the taxation of the digital economy. ${ }^{24}$

\subsection{INDIA}

India stance on digital taxation is also similar to the Nigerian approach, with the Indian Finance Act seeking to subject businesses that have 'significant economic presence' in Nigeria to pay tax regardless of such business not having a physical presence in India. ${ }^{25}$

\subsection{CONCLUSION AND RECOMMENDATION}

The emergence of the Finance Act in Nigeria is a major step towards the taxation of digital activities but there is still a long road ahead for an effective system of taxation of online activities, due to lack of international consensus on the taxation of online activities, lack of enforcement procedure given the absence of physical presence which makes effective tracking difficult $^{26}$, looming fear over double taxation and overall a growing distrust by the masses over tax regulations which ultimately leads to tax avoidance. Hence, a need arises for the government to provide immediate solutions to meet the present challenges by giving out appropriate guidelines for taxing online activities, cooperating with national and international organizations on developing a framework for the taxation of online activities and most importantly educating the masses on the importance of taxing the digital economy.

\footnotetext{
${ }^{24}$ Emmanuel Paul, 'Inside Kenya's Plan to Enforce Taxes on Google, Netflix, Digital Services'(Techpoint.africa, 16 June 2020) https://techpoint.africa/2020/06/16/kenya-enforce-tax-digital-services/ accessed 26th August 2020. ${ }^{25}$ Ogochukwu Isiadinso and Emmanuel Omoju, Taxation of Nigeria's Digital Economy: Challenges and Prospects (Mondaq, 30 May 2019) http://www.mondaq.com/nigeria/tax-authorities/810276/taxation-of-nigeria39s-digitaleconomy-challenges-and-prospects accessed 26th August 2020.

26 Ibid.
} 


\section{BIBLIOGRAPHY}

\section{TABLE OF CASES}

- Prime Plastichem Nigeria Limited V FIRS TAT/LZ/CIT/015/2017

- Vodacom Business Nigeria Limited v FIRS (2019) LPELR-47865(CA)

\section{TABLE OF STATUTES}

- Companies Income Tax Act 2007

\section{SECONDARY SOURCES}

\section{ONLINE NEWSPAPERS}

- AGO Group, 'Coronavirus-Africa: Taxing the digital economy- COVID-19 heightens need to expand resource mobilization base' The Guardian (26 August 2020) https://guardian.ng/apopress-releases/coronavirus-africa-taxing-the-digital-economy-covid-19-heightens-need-toexpand-resource-mobolization-base/ accessed $26^{\text {th }}$ August 2020.

- Udegbunam O, 'ICT's Contribution to Nigeria's GDP increases in spite of economic slowdown' Premiumtimesng (Abuja, 25 August 2020) https://www.premiumtimesng.com/business/410695icts-contribution-to-nigerias-gdp-increases-in-spite-of-economic-slowdown.html accessed 26th August 2020.

\section{ONLINE ARTICLES}

- 'VAT Challenges for the Digital Economy' (KPMG) https://home.kpmg/xx/en/home/insights/2019/01/vat-challenges-for-the-digital-economy.html accessed $26^{\text {th }}$ August 2020.

- 'FIRS Issues Information Circular on the Implementation of VAT Changes in the Finance Act' (Proshare, 5 May 2020) https:///www.proshareng.com/news/Taxes\%20\&\%20Tariffs/FIRS- 
$\underline{\text { Issues-Information-Circular-on-the-Implementation-of-VAT-Changes-in-the-Finance-Act/50857 }}$ accessed $1^{\text {st }}$ September 2020.

- Adegite V and Obayemi W, 'Taxation of Digital Economy in Nigeria-Significant Economic Presence' (Bloomberg Tax, 31 December 2019) https://newa.bloombergtax,com/digital-taxreport-international/insight-taxtion-of-digital-economy-in-nigeria-significant-economic-presence accessed $26^{\text {th }}$ August 2020.

- Eleanya F, 'Nigeria’s Digital Tax Plan Could Unlock New Revenue, but hurdles lie ahead'(Business Day, 30 June 2020) https://businessday.ng/technology/article/nigerias-digitaltax-plan-could-unlock-new-revenuse-but-hurdles-lie-ahead accessed 26 $6^{\text {th }}$ August 2020.

- Eze U and Medidem I, 'Taxation of Non-Resident Companies with Significant Economic Presence in Nigeria'(Proshare, 4 August 2020) http://www.proshareng.com/news/Taxes\%20\&\%20Tarrifs/Taxation-of-Non-ResidentCompanies-with-Significant-Econonic-Presence-in Nigeria/52579 accessed 26 ${ }^{\text {th }}$ August 2020.

- Folarin F, Arowolo S and Olugbenro Y, 'why should tax be on digital flight from Nigeria?' (Deloitte) https://www2.deloitte.com/ng/en/pages/tax/articles/inside-tax-articles/why-should-taxbe-on-digital-flight-from-nigeria.html accessed 26th August 2020.

- Idowu A, Adegite V and Obayemi W, 'Taxation of Digital Economy in Nigeria's Finance Bill' (Enugumetro 31 May 2020) https://enugumetro.com/taxation-of-digital-economy-in-nigeriasfinance-bill-2019 accessed 26 $6^{\text {th }}$ August 2020.

- Idris A, 'Inside the Finance Bill: Nigeria is Planning to Introduce Digital Taxes' (Techcabal, 15 January 2020) https://techbal.com/2020/01/15/inside-the-finanace-bill-nigeria-is-planning-tointroduce-digital-taxes accessed $26^{\text {th }}$ August 2020.

- Ikosa C, 'ICT is the New Oil Government Should Bring Up Polices to Make things Better'(Businessamlive,24 August 2020) https://www.businessamlive.com/ict-is-new-oil- 
government-should-bring-up-policies-to-make-things-better-ogungboye-ceo-estream-networks/ accessed $26^{\text {th }}$ August 2020.

- Isiadinso O and Omoju E, Taxation of Nigeria's Digital Economy: Challenges and Prospects (Mondaq, 30 May 2019) http://www.mondaq.com/nigeria/tax-authorities/810276/taxation-ofnigeria39s-digital-economy-challenges-and-prospects accessed 26th August 2020.

- Komolafe D and Chukwani O, 'The Impact of the Finance Act on Digital Taxation in Nigeria'(Mondaq 21 May 2020) < https://www.mondaq.com/nigria/tax-authorities/903148/theimpact-ofthe-finance-act-on-digital-taxation-in-nigeria> accessed $26^{\text {th }}$ August 2020.

- Paul E, 'Inside Kenya’s Plan to Enforce Taxes on Google, Netflix, Digital Services'(Techpoint.africa, 16 June 2020) https://techpoint.africa/2020/06/16/kenya-enforce-taxdigital-services/ accessed 26th August 2020. 
